\title{
The family Histriobdellidae (Annelida, Polychaeta) including descriptions of two new species from Brazil and a new genus
}

\author{
Tatiana Menchini Steiner \& A. Cecilia Z. Amaral \\ Departamento de Zoologia, Instituto de Biologia, Universidade Estadual de Campinas/UNICAMP, Caixa \\ Postal 6109, 13083-970, Campinas, SP, Brazil.
}

Keywords: Polychaeta, Histriobdellidae, family review, sýstematics, new genus, new species

\begin{abstract}
We review the family Histriobdellidae and provide species descriptions and notes on geographical distribution based on data from the literature. The morphological structures used in the systematics of this family are defined. A new genus, Dayus, is proposed and two new species from Brazil, Stratiodrilus robustus and $S$. circensis, are described.
\end{abstract}

\section{Contents}

$\begin{array}{lr}\text { Abstract } & 95 \\ \text { Introduction } & 95 \\ \text { Considerations on some morphological structures } & 96 \\ \text { Systematic biology } & 97 \\ \text { Histriobdellidae Vaillant, 1890 } & 97 \\ \quad \text { Histriobdella Van Beneden, 1858 } & 100 \\ \text { Histriobdella homari Van Beneden, 1858 } & 100 \\ \text { Stratiodrilus Haswell, 1900 } & 100 \\ \text { Stratiodrilus tasmanicus Haswell, 1900 } & 100 \\ \text { Stratiodrilus novaehollandiae Haswell, 1913 } & 101 \\ \text { Stratiodrilus platensis Cordero, 1927 } & 101 \\ \text { Stratiodrilus haswelli Harrison, 1928 } & 102 \\ \text { Stratiodrilus aeglaphilus Vila \& Bahamonde, } 1985 & 102 \\ \text { Stratiodrilus pugnaxi Vila \& Bahamonde, 1985 } & 103 \\ \text { Stratiodrilus arreliai Amaral \& Morgado, 1997 } & 103 \\ \text { Stratiodrilus robustus } \text { n. sp. } & 105 \\ \text { Stratiodrilus circensis n. sp. } & 106 \\ \text { Dayus n. gen. } & 107 \\ \text { Dayus cirolanae n. comb. } & 107 \\ \text { Acknowledgements } & 107 \\ \text { References * } & 107\end{array}$

\section{Introduction}

The family Histriobdellidae was erected by Vaillant in 1890. Its representatives are ectosymbionts liv- ing on marine and freshwater isopod and decapod crustaceans. Several epizoic groups, including histriobdellids and protozoans, platyhelminths, nematodes, rotifers, annelids, ostracods, and copepods may occur in association on the general body surface (head, thorax, abdomen, or appendages), or within the bränchial chambers (on the gills, epipodites, or inner surfaces of the carapace) of the hosts. Interactions of the various symbionts with their hosts, including nutritional, physiological, and ecological aspects, as well as the problem of defining the parasitic interactions among them, have been studied by several authors (Uzmann, 1967; Simon, 1968; Dioni, 1972; Jennings \& Gelder, 1976; Boghen, 1978; Brattey \& Campbell, 1985; Cannon \& Jennings, 1987).

Histriobdella Van Beneden, 1858 was the first genus described in the family. It is represented by only one marine species, $H$. homari, which occurs exclusively on lobsters (Homarus, Nephrops) in the Northern Hemisphere (Europe, Canada, and the United States). Many studies have been performed on the anatomy and embryology of this species (Van Beneden, 1858; Foettinger, 1884; Shearer, 1910; Mesnil \& Caullery, 1922; Gelder \& Jennings, 1975; Jamieson et al., 1985). Its physiology (Jennings \& Gelder, 1976; Gelder \& Tyler, 1986) and behavior and ecology (Uzmann, 1967; Simon, 1968; Boghen, 1978; Brattey \& Campbell, 1985; Van Engel et al., 1986; Lerch \& Uglem, 1996) have also been the object of several investigations.

The genus Stratiodrilus was proposed by Haswell in 1900 to encompass species living on freshwater decapod crustaceans of the Southern Hemisphere. From 1900 to the present, ten species have 
been identified on different hosts (Astacopsis, Astacoides, Aegla, Cherax, Parastacus, Samastacus, and Trichodactylus) from Tasmania, Australia, Madagascar, Chile, Argentina, Uruguay, and Brazil. The several published reports on this group range from brief descriptions of new species, to studies of anatomy (Haswell, 1900, 1913; Lang, 1949; Roubaud, 1962), embryology (Haswell, 1916), behavior, feeding habits, and symbiotic interactions (Cordero, 1927; Dioni, 1972; Cannon \& Jennings, 1987; Moyano et al., 1993).

Führ (1971) described Stratiodrilus cirolanae from South Africa, a commensal species living on the pleopods of the marine isopod Cirolana venusticauda var. simplex Barnard. This is the only record of a marine member of this family in the Southern Hemisphere.

The present study considers the morphological terms used in describing members of the family, summarizes the geographical distributions of the taxa, and describes two new species from Brazil. A new genus is also proposed for the species described by Führ (1971). The main characters of other species of the family, including the new genus, are described based on literature data, except for Stratiodrilus platensis Cordero, 1927 and S. arreliai Amaral \& Morgado, 1997.

Besides the species of Stratiodrilus included here, Moyano et al. (1993) referred to a new species, which has not been formally described.

\section{Considerations on some morphological structures}

The family has been assigned to several taxa, such as Hirudinea, Rotifera, and Archiannelida. In this century, based on comparative studies, several authors (Mesnil \& Caullery, 1922; Gelder \& Jennings, 1975; Jennings \& Gelder, 1976) placed the histriobdellids in the order Eunicida (near the family Eunicidae), as a highly specialized commensal, lacking external resemblance to the traditional Errantia pattern.

We attempt to compare the external morphological structures of the histriobdellids with those usually used for other polychaete taxa. We also review certain terms used in the systematics of this family. However, the embryology and functions of some structures remain unknown. The structures are shown in Figs. 1, 2a, 3a, and 4.

Body division: according to studies on anatomy and morphology (Van Beneden, 1858; Haswell, 1900; 1913; Shearer, 1910; Gelder \& Jennings, 1975), histriobdellids have the body divided into three parts: head (Hd), trunk (Tr), and posterior region $(\mathrm{Pr})$. The head is composed of the prostomium fused to the peristomium, seven appendages, and the jaw apparatus. The trunk consists of five segments. The first segment bears no cirri, and in this study is termed simply "first segment of the trunk" (sometimes called neck). Segments 2, 3, and 5 may or may not bear lateral cirri. The posterior region includes a constriction that ends in two laterally directed expansions. Several fused segments compose that region, which is confirmed by the presence of several fused ganglia along the ventral nerve cord.

Anterior locomotor appendages (Al): the pair of head appendages located ventrolaterally on the peristomium. These aid in locomotion, fixation on the host, and feeding. They are retractile, and are also known as anterior limbs. Fauchald \& Rouse (1997) termed them peristomial cirri because they are located on the peristomium. Other families of the order Eunicida have the peristomial cirri located dorsally and posteriorly on the peristomium. George \& Hartmann-Schröder (1985) called them modified parapodia. We chose the designation anterior locomotor appendages because of their function.

Posterior locomotor appendages (PI): formed by the two laterally directed expansions of the pygidium, commonly called posterior limbs or feet. These pygidial lobes contain the anus and bear the posterior cirri, which may be modified pygidial cirri, as shown in the eunicids. These appendages aid in locomotion and fixation on the host.

Antennae (T1-T3) and cirri (C1-C5): may be segmented or not. Both structures have sensory cilia on their distal end. Lang (1949) did not confirm their presence in one species of Stratiodrilus. The genus Histriobdella has no cilia. Roubaud (1962), studying a South American species of Stratiodrilus, pointed out that the cirri and antennae beâr a structure called "pied" [foot], lending 
a segmented appearance. We succeeded in locating the "pied" in several individuals, but it was not a constant character.

Antennae (T1-T3): George \& Hartmann-Schröder (1985), Fauvel (1923), and Fauchald \& Rouse (1997) pointed out that histriobdellids have 3 antennae and 2 palps, rather than 5 antennae. The designation palp or antenna is based on the innervation of these structures from the brain (Fauchald \& Rouse, 1997). The second pair of antennae, located posteriorly and laterally on the head, may be peristomial cirri, because of their position. For the purposes of the present report, we will consider them antennae, because of their sensory function as well.

Lateral cirri (C1-C3): termed simple when only one isolated cirrus is present. This cirrus may be forked (as in Stratiodrilus haswelli) or paired. The paired condition occurs when two cirri emerge from the side of each segment, independent at the base, as in Dayus cirolanae (Führ, 1971) n. comb.

Posterior cirri (C4-C5): termed simple when only one isolated cirrus is present on each of the posterior appendages. When there are two branches emerging from a common base, these may be a double cirrus or a simple cirrus plus a lobe (as in Stratiodrilus circensis n. sp.). The end of the body is characterized by the presence of the anus, thus the posterior appendages are, in fact, lateral expansions of the body. The cirri are numbered from $\mathrm{C} 1$ to C5 (except in Histriobdella) from the anterior region to the posterior region, toward the anus. When more than one pair of cirri is present in the posterior region, the pair nearest to the anus is called C5. Because Histriobdella has no lateral cirri, the two simple cirri that are located on the posterior appendages are termed posterior cirri.

Lobe (Lb): we consider this structure to be taxonomically important, because when present (close to the C4), it shows significant interspecific variation in shape and size. Lobes are morphologically different from cirri, being unsegmented and lacking cilia on their distal ends.

Tubercles (Tb): small rounded structures, similar to the cirri and always simple. Tubercles are highly retractile and may bear cilia on their distal ends. Tubercles may be absent in some species.

Claspers (CL): Roubaud (1962) pointed out that
South American species lack claspers. Some authors have noted the presence of these structures, but others have made no mention of them. Of all the South American specimens examined by us, only one male bore a structure that may be a clasper.

Jaw apparatus (Mx, Md) and penis (P): Haswell (1900) indicated that the penis is polymorphic. However, according to Roubaud (1962) these structures change shape according to the stage of growth of the animal.

\section{Systematic biology}

The holotypes and paratypes of the two new species, Stratiodrilus robustus and $S$. circensis, as well as all other specimens examined, are deposited in the polychaete collection (MHNBPO) of the Museu de História Natural da Universidade Estadual de Campinas, Campinas, State of São Paulo, Brazil.

\section{Histriobdellidae Vaillant, 1890}

Small and delicate, maximum length $1.5 \mathrm{~mm}$. Body wormlike, indistinctly and irregularly annulated with constrictions more visible laterally, and divided into head, trunk, and posterior region. Head with prostomium frontally rounded, fused to peristomium. Eyes, true parapodia, aciculae, and chaetae lacking. Five antennae: one frontal pair, one single median, one dorsolateral pair. One pair of retractile locomotor appendages, located lateroventrally on middle part of head, and bearing adhesive glands on distal ends. Trunk with 5 segments, last 4 segments with or without lateral cirri. Males with one pair of lateral retractile claspers near fourth trunk segment, and chitinous penis on ventral side of body. Posterior region composed of many fused segments, its anterior portion characterized by large constriction ending in two lateral pygidial lobes (posterior locomotor appendages), These appendages have adhesive glands on their distal ends, cirri, lobes, and tubercles. Antennae, cirri, and tubercles may bear sensory cilia on their distal ends. Jaw apparatus black, chitinous, and very complex, enclosed in pharyngeal sac on ventral side of esophagus. Jaw apparatus arranged in two sets: upper jaws, formed by very 


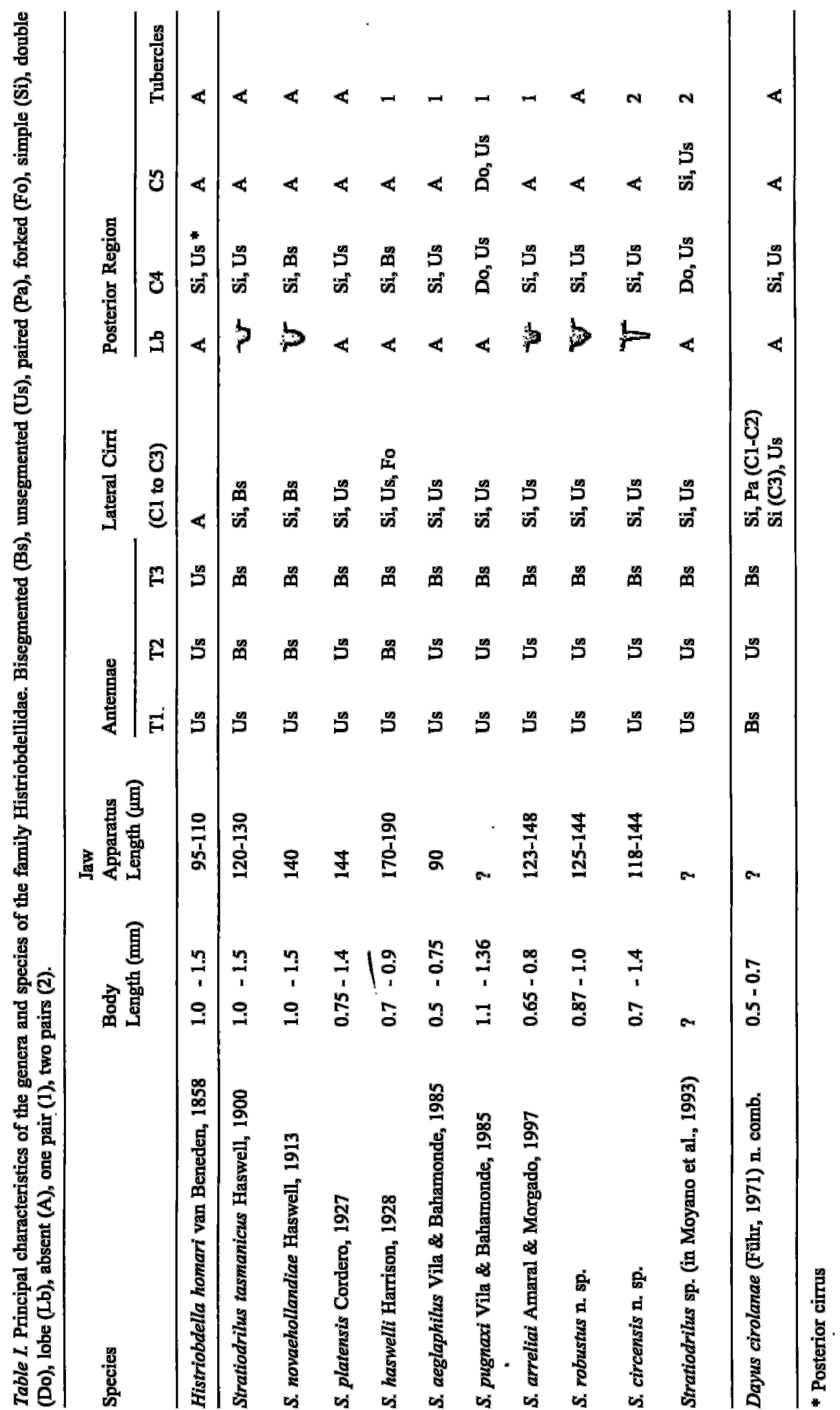


Table II. Hosts, records of occurrence, and sources of information for the species of the family Histriobdellidae.

\begin{tabular}{|c|c|c|c|}
\hline Species & Host & Occurrence & References \\
\hline \multirow[t]{18}{*}{ Histriobdella homari Van Beneden, 1858} & Nephrops norvegicus & Norway, France & Van Beneden, 1858 \\
\hline & Homarus vulgaris & England & Shearer, 1910 \\
\hline & On homarids & France & Mesnil \& Caullery, 1922 \\
\hline & & & Fauvel, 1923 \\
\hline & Homarus vulgaris & England & Gelder \& Jennings, 1975 \\
\hline & & & Jennings \& Gelder, 1976 \\
\hline & * & British Isles & George \& Hartmann- \\
\hline & × & & Schröder, 1985 \\
\hline & Nephrops norvegicus & & \\
\hline & Homarus vulgaris & & Briggs et al, 1997 \\
\hline & Homarus sp. & & \\
\hline & Homarus americanus & The United States & Uzmann, 1967 \\
\hline & On lobsters & & Simon, 1968 \\
\hline & Homarus americanus & & Gelder \& Jennings, 1975 \\
\hline & & & Jennings \& Gelder, 1976 \\
\hline & & & Van Engel et al., 1986 \\
\hline & Homarus americanus & Canada & Boghen, 1978 \\
\hline & & & Brattey \& Campbell, 1985 \\
\hline \multirow[t]{3}{*}{ Stratiodrilus tasmanicus Haswell, 1900} & Astacopsis franklinii & "Tasmania & Haswell, 1900 \\
\hline & Astacopsis franklinii var. & - & \\
\hline & tasmanicus & & Harrison, 1928 \\
\hline \multirow[t]{3}{*}{ S. novaehollandiae Haswell, 1913} & Astacopsis serratus & Australia & Haswell, 1913 \\
\hline & Cherax dispar & & Cannon \& Jennings, 1987 \\
\hline & Cherax punctatus & & \\
\hline \multirow[t]{2}{*}{ S. platensis Cordero, 1927} & Aegla laevis & Uruguay & Cordero, 1927 \\
\hline & Trichodactylus sp. & Brazil & present paper \\
\hline S. haswelli Harrison, 1928 & Astacoides madagascariensis & Madagascar & Harrison, 1928 \\
\hline \multirow[t]{2}{*}{ S. aeglaphilus Vila \& Bahamonde, 1985} & $\begin{array}{l}\text { Aegla laevis laevis } \\
\text { Aegla laevis talcahuano }\end{array}$ & Chile & $\begin{array}{l}\text { Vila \& Bahamonde, } 1985 \\
\text { Moyano et al., } 1993\end{array}$ \\
\hline & Other Aeglidae and Parastacidae & & * \\
\hline \multirow[t]{3}{*}{ S. pugnaxi Vila \& Bahamonde, 1985} & Parastacus pugnax & & Vila \& Bahamonde, 1985 \\
\hline & Parastacus pugnax & & Moyano et al, 1993 \\
\hline & $\begin{array}{l}\text { Parastacus sp. } \\
\text { Other Aeglidae and Parastacidae }\end{array}$ & & \\
\hline Stratiodrilus sp. (in Moyano et al., 1993) & On Aeglidae and Parastacidae & & Moyano et al, 1993 \\
\hline \multirow{2}{*}{ S. arreliai Amaral \& Morgado, 1997} & Aegla perobae & Brazil & Amaral \& Morgado, 1997 \\
\hline & Aegla sp. & & present paper \\
\hline S. robustus n. sp. & Trichodactylus sp. & . & present paper \\
\hline \multirow[t]{5}{*}{ S. circensis n. sp. } & Aegla laevis & $\begin{array}{l}\text { Argentina } \\
\text { Chile }\end{array}$ & Lang, 1949 \\
\hline & Aegla neuquensis neuquensis & Argentina & Roubaud, 1962 \\
\hline & Aegla bahamondel & Chile & Moyano et al, 1993 \\
\hline & $\begin{array}{l}\text { Aegla abtao } \\
\text { Other Aeglidae and Parastacidae }\end{array}$ & & \\
\hline & Aegla sp. & Brazil & present paper \\
\hline Dayus cirolanae (Führ, 1971) n. comb. & Cirolana venusticauda var. simplex & South Africa & Führ (1971) \\
\hline
\end{tabular}

long axial piece and a sequence of lateral small articulated pieces on its upper end, and lower jaw, formed by two long posterior rods, enlarged anteriorly.
The species are dioecious and sexually dimorphic when mature. Egg-laying occurs in the branchial chamber or in egg masses carried by the female host. Eggs are attached at one end or on 
their sides, depending on the genus. Development is direct, with no free-living larval stage, and miniatures of immature adults hatch from the eggs.

The principal characters of the genus and species of the family are compared in Table I. Table II summarizes the geographical distributions of the taxa.

\section{Histriobdella Van Beneden, 1858}

Diagnosis. - Antennae unsegmented, short and robust with no sensory cilia, all of approximately the same length. Anterior appendages not retractile. Mouth ventral. Lateral cirri absent. Posterior region composed of three fused segments, and bearing simple unsegmented cirri. Females attach the eggs to the host by one end.

Type-species, - Histriobdella homari Van Beneden, 1858

Discussion. - The single species of the genus lives exclusively on marine decapod crustaceans.

\section{Histriobdella homari Van Beneden, 1858}

Histriobdella homari Van Beneden, 1858: 270-303, figs. 1-14; Shearer, 1910: 287-359, figs. 1-3, plates 17-20.

Description. - Total body length of adults ranging from 1.0 to $1.5 \mathrm{~mm}$; length of jaw apparatus from 95 to $110 \mu \mathrm{m}$. All antennae unsegmented, measuring approximately $1 / 3$ of head length. Trunk segments similar in length. Claspers present. Each posterior appendage with simple unsegmented cirrus, smaller than antennae. Tubercles and lobes absent. Jaw apparatus short, its posterior end not reaching trunk.

Distribution and hosts. - Europe: coasts of France, Belgium, the Netherlands, England (English Channel, North Sea), Scotland (Clyde Sea), Norway, Ireland (Irish Sea), on Nephrops norvegicus (Linnaeus), Homarus vulgaris (Milne-Edwards), and Homarus sp.; - United States: Massachusetts (Na- hant, Woods Hole, Great Harbor), on lobsters; New England (Cutler, Southwest Harbor, Monhegan Island, Boothbay Harbor, Portsmouth, Milford, Georges Bank), on Homarus americanus MilneEdwards; - Canada: Bay of Fundy, southern and western coast of Nova Scotia, German Bank and Browns Bank, Northumberland Strait (south of Gulf of St. Lawrence), on $H$. americanus. Gelder \& Jennings (1975), studying the nervous system of $H$. homari, concluded that there are no differences between American and European populations. However, Jamieson et al. (1985) considered that the two populations maybe do not represent the same species.

\section{Stratiodrilus Haswell, 1900}

Diagnosis. - Median antenna (T1) unsegmented and generally shorter than the first pair (T2), which may be bisegmented; second lateral pair (T3) always longer than the others and may be bisegmented. Mouth anterior. Lateral cirri $(\mathrm{Cl}, \mathrm{C} 2$ and C3) simple, may be bisegmented; forked in one species. Anterior appendages retractile. Posterior region composed of five fused segments, may have cirri (with lobes close to C4) and tubercles. Antennae, cirri, and tubercles with sensory cilia on their distal ends. Eggs are attached to the host by their sides, a character exclusive to this genus.

Type-species. - Stratiodrilus tasmanicus Haswell, 1900

Discussion. - The species belonging to the genus Stratiodrilus live exclusively on freshwater decapod crustaceans. Members of this genus have simple unpaired lateral cirri, a well-defined posterior region, and a more organized nervous system than Histriobdella.

Stratiodrilus tasmanicus Haswell, 1900

Stratiodrilus tasmanicus Haswell, 1900: 299-335, figs. 1-17; Harrison, 1928: 118.

Description. - Total body length ranging from 1.0 to $1.5 \mathrm{~mm}$. Length of jaw apparatus from 120 to 
$130 \mu \mathrm{m}$. Antennae as follows: median antenna (T1) very thin, length $1 / 6$ as long as head length; first lateral pair (T2) slightly longer than median antenna; second lateral pair (T3) nearly twice as long as first pair (T2); both lateral pairs bisegmented (in T2, basal portion shorter than distal portion). Anterior locomotor appendages basally broad, distally tapered, almost as long as second pair of antennae. First trunk segment $1 / 4$ as long as head length. Lateral cirri (C1-C3) simple, bisegmented, slightly longer than first pair of antennae. Claspers slightly longer and more robust than anterior appendages. Each posterior locomotor appendage with one simple, unsegmented cirrus (C4), similar in length to median antenna, and small quadrate lobe, shorter than C4. Posterior end of jaw apparatus not reaching trunk.

Discussion. - The brief description by Harrison (1928) and the information about the species given by Vila \& Bahamonde (1985) in their figure 1 and identification key agree entirely with the original description by Haswell (1900). The pictorial key by Moyano et al. (1993) showed the pair of conical lobes of the posterior appendages as being a part of the C4. Stratiodrilus tasmanicus would therefore have one pair of double cirri instead of one pair of simple cirri. However, according to the original description, only one posterior simple cirrus and a conical lobe on each appendage are evident.

Distribution and hosts. - Tasmania (streams in the neighborhood of Hobart), on Astacopsis franklinii Gray and A. franklinii var. tasmanicus Erickson.

\section{Stratiodrilus novaehollandiae Haswell, 1913}

Stratiodrilus novaehollandiae Haswell, 1913: 197-226, fig. 1, pls. 11-14; Harrison, 1928: 119, fig. 1 .

Description. - Total body length ranging from 1.0 to $1.5 \mathrm{~mm}$; jaw apparatus with mean length 140 $\mu \mathrm{m}$. Median antenna (T1) very small, first pair (T2) bisegmented and longer than median antenna; second pair (T3) almost twice as long as first pair and also bisegmented. Anterior locomotor appendages somewhat shorter than T3. Lateral cirri (C1-
C3) simple, bisegmented, almost as long as T3. Claspers longer than anterior locomotor appendages. Posterior region with one pair of simple bisegmented cirri (C4), as long as lateral cirri. One papilliform lobe, shorter than $\mathrm{C} 4$, on each appendage. Posterior end of jaw apparatus not reaching trunk.

Discussion. - The description by Harrison (1928) agrees very well with the original description by Haswell (1913). According to the identification key by Vila \& Bahamonde (1985), S. novaehollandiae is included among species that have double cirri C4. Haswell (1913) did not mention the presence of double $\mathrm{C} 4$. The second cirrus of the pair described by these authors may be the conical lobe close to the C4. The first pair of antennae (T2) is considered here to be bisegmented, in agreement with the. original description.

Distribution and hosts. - Australia: Blue Mountains, New South Wales, in streams at elevations of about 600 to 900 meters, Cataract River and Loddon River, Waterfall Creek, creeks running into Middle Harbour, Port Jackson and Pitt Water off Broken Bay, Murray River system (Murrumbidgee River), on Astacopsis serratus Shaw; Gap Creek, Mount Coottha, Queensland, on Cherax dispar Riek and Cherax punctatus Clark.

\section{Stratiodrilus platensis Cordero, 1927}

Stratiodrilus platensis Cordero, 1927: 574-578, fig. 1. Stratiodrilus sp.: Harrison, 1928: 121, fig. 3.

Material examined, - One female, adult specimen, MHN-BPO64, host Trichodactylus sp., creek near Cananéia, State of São Paulo, Brazil, coll. Dr. Edmundo F. Nonato, 27.VIII.1978.

Description. - Total body length $0.75 \mathrm{~mm}$; jaw apparatus $144 \mu \mathrm{m}$ long. Median antenna (T1) half as long as first lateral pair (T2), which is unsegmented and 1/6 as long as head length. Second pair of antennae (T3) bisegmented, twice as long as first pair. Anterior locomotor appendages almost as long as T3. First segment of trunk half as long as head length. Lateral cirri (C1-C3) simple, unsegmented, as long as median antennae. Poste- 
rior region with one pair of unsegmented simple cirri (C4), equal in length to first pair of antennae. Jaw apparatus robust, posterior end reaching midlength of first trunk segment.

Discussion. - The characters observed on the specimen examined here agree with the description by Harrison (1928) for Stratiodrilus sp. from Uruguay. The most important characters are the presence of only one pair of simple cirri $\mathrm{C} 4$, and of very short antennae and lateral cirri (C1-C3). Both Lang (1949), in a study on morphology and anatomy, and Vila \& Bahamonde (1985), in their identification key, stated that $S$. platensis has one pair of double cirri C4. Moyano et al. (1993: fig. 2) showed two pairs of tubercles for this species, in addition to one pair of double cirri (C4). Amaral \& Morgado (1997) adopted these characters as well. However, all these references and observations do not agree with the original description of $S$. platensis, but instead constitute characters of another species, described here as $\boldsymbol{S}$. circensis n. sp. The second pair of antennae (T2) is not regarded here as being bisegmented as indicated by Cordero (1927), since this character could not be verified.

Distribution and hosts. - Uruguay: Solís Chico and Miguelete streams, Department of Canelones, on Aegla laevis (Latreille); - Brazil: creeks near Cananéia, State of São Paulo, on Trichodactylus sp.

\section{Stratiodrilus haswelli Harrison, 1928}

Stratiodrilus haswelli Harrison, 1928: 119-121, fig. 2.

Description. - Small species, total body length 0.7 $-0.9 \mathrm{~mm}$; jaw apparatus $170-190 \mu \mathrm{m}$ long. Antennae as follows: first lateral pair (T2) bisegmented, slightly longer than median antenna (T1); second lateral pair (T3) twice as long as T2 and also bisegmented. Anterior locomotor appendages basally wide and distally tapered, slightly longer than T3. Lateral cirri (C1-C3) simple, unsegmented, forked distally, as long as second pair of antennae; minute sensory papilla present in angle of each cirrus. Claspers similar in form and length to an- terior appendages. Posterior region with one pair of simple, bisegmented cirri (C4) and one tubercle present at end of each appendage. Jaw apparatus robust and large, its posterior end reaching midlength of first trunk segment.

Discussion. - This species is known only from the original description. Vila \& Bahamonde (1985: fig. 1) depicted the cirrus $\mathrm{C} 4$ as being $\mathrm{C}$, and the tubercle on the posterior border of the posterior appendage as being a $\mathrm{C} 4$ cirrus. However, the distinction between these two structures is very clear in the original species description.

Distribution and host. - Madagascar, on Astacoides madagascariensis Milne-Edwards.

Stratiodrilus aeglaphilus Vila \& Bahamonde, 1985

Stratiodrilus aeglaphilus Vila \& Bahamonde, 1985: 348-349, fig. 1 .

Description. - Small species, mean length $0.75 \mathrm{~mm}$ for males and $0.5 \mathrm{~mm}$ for females. Jaw apparatus of both sexes with mean length $90 \mu \mathrm{m}$. Antennae as follows: median (T1) and first lateral pair (T2). smaller than second pair (T3), the latter almost three times as long as median antenna; T2 unsegmented and T3 bisegmented. Locomotor appendages of head longer than first pair of antennae. Lateral cirri (C1-C3) simple, unsegmented, almost of same length as second pair of antennae. Claspers almost three times as long as anterior appendages. Posterior region with one pair of simple, unsegmented cirri (C4); these as long as lateral cirri and with one pair of tubercles. Posterior end of jaw apparatus not reaching first trunk segment.

Discussion, - Vila \& Bahamonde (1985: fig. 1) showed an undefined structure near the median antenna, longer than the second pair of antennae, which does not appear in the brief description of the species and is probably the anterior region of the pharynx. Moyano et al. (1993: fig. 2) showed this species as having two pairs of tubercles, rather than the single pair mentioned in the original descriptiön. 
Distribution and hosts. - Chile: Maipo River, on Aegla laevis laevis (Latreille); "estero" Bellavista, on Aegla laevis talcahuano Schmitt; from Petorca to Chiloé, on several unspecified species of the families Parastacidae and Aeglidae.

Stratiodrilus pugnaxi Vila \& Bahamonde, 1985

Stratiodrilus pugnaxi Vila \& Bahamonde, 1985: 349-350, fig. 1 .

Description. - Animal robust. Mean total body length $1.2 \mathrm{~mm}$ (maximum $1.36 \mathrm{~mm}$ ) for males and $1.1 \mathrm{~mm}$ (maximum $1.18 \mathrm{~mm}$ ) for females. Antennae as follows: median (T1) and first lateral pair (T2) unsegmented; second pair (T3) longer than first pair and bisegmented. Lateral cirri ( $\mathrm{C} 1-\mathrm{C} 3)$ simple, unsegmented, as long as second lateral pair (T3). Tail with one pair of cirri $\mathrm{C} 4$ and one pair of $\mathrm{C} 5$, both double and unsegmented, as long as median antenna (T1). One tubercle present on posterior border of each locomotor appendage. Jaw apparatus robust, reaching part of first trunk segment.

Discussion. - According to the description of Vila \& Bahamonde (1985), the jaw apparatus was 430 $\mu \mathrm{m}$ long, which would represent $1 / 3$ of the total body length; therefore the size given cannot be correct. According to their figure, this species would have more than one pair of antennae close to the region of the anterior appendages, as well as having this antenna (T3) with three portions or segments. These characters are not mentioned in the description itself and are unknown in Stratiodrilus. Another ambiguous interpretation occurs with the cirri of the posterior region. Thus, the original description referred to four pairs of cirri and the original figure showed the $\mathrm{C} 4$ pair as being cirrus $\mathrm{C} 6$ and $\mathrm{C} 7$ and the $\mathrm{C} 5$ pair as being $\mathrm{C} 5$ and $\mathrm{C} 4$. Moyano et al. (1993: fig. 3) raised doubts as to whether $\mathrm{C} 5$ and one of the $\mathrm{C} 4$ rami are in fact cirri, since the form of these structures much more resembles a lobe. Moyano et al. (1993) also depicted the tubercles as being two pairs rather than the single pair mentioned in the original description.

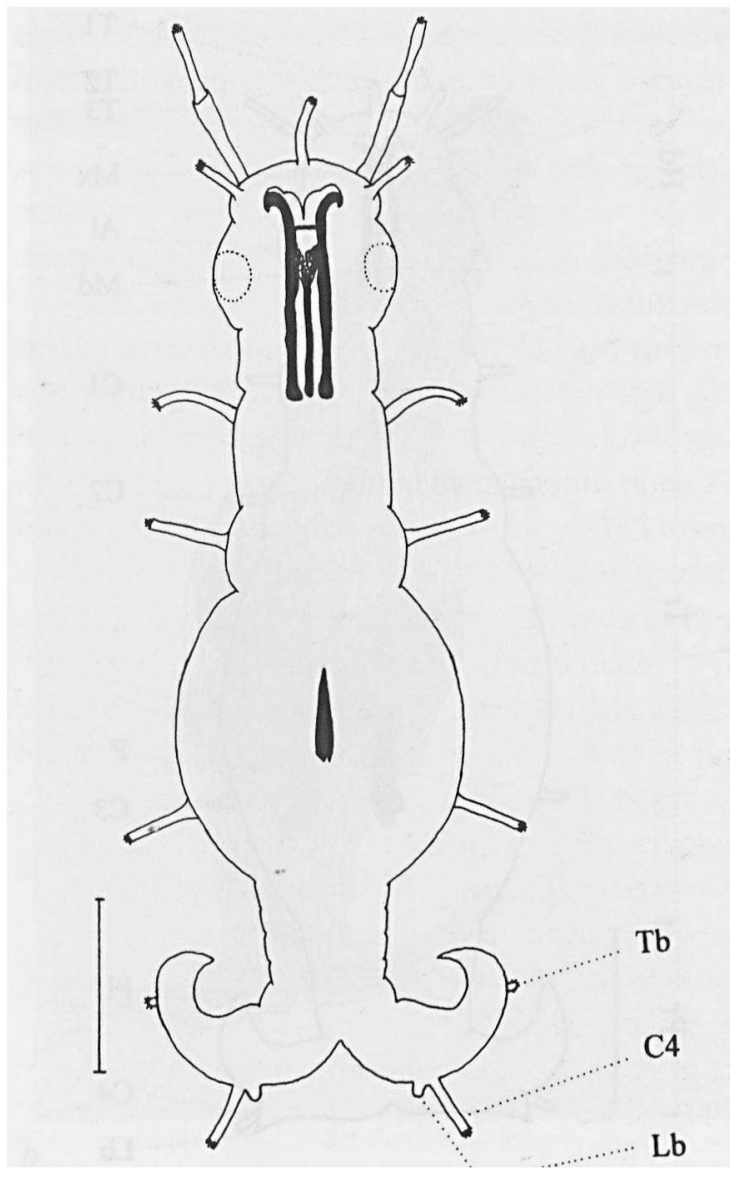

Fig. 1. Stratiodrilus arreliai Amaral \& Morgado, 1997 (ventral view). Male. Abbreviations as in Fig. 2a. Scale bar: $150 \mu \mathrm{m}$. Adapted from Amaral \& Morgado (1997).

Distribution and hosts. - Chile: Reúmen (Valdivia), on Parastacus pugnax (Poeppig); Chaimávida, near Concepción, on Parastacus pugnax and Parastacus sp.; from Petorca to Chiloé, on several unspecified species of the families Parastacidae and Aeglidae.

Stratiodrilus arreliai Amaral \& Morgado, 1997 (Fig. 1)

Stratiodrilus arreliai Amaral \& Morgado, 1997: 471-475, figs. 1-2.

Material examined. - Holotype, MHN-BPO-54 (Museu de História Natural, Universidade Estadual de Campinas, State of São Paulo, Brazil), host Aegla perobae, from Peroba Cave, 


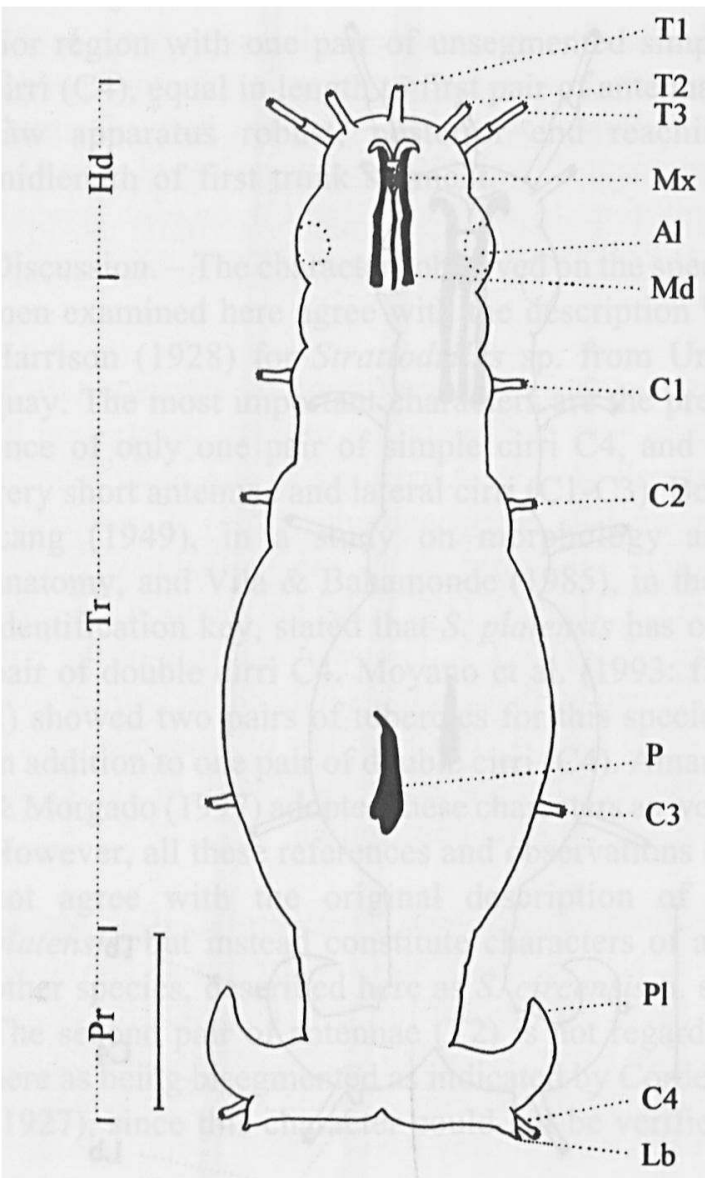

a.

Fig. 2. (a) Stratiodrilus robustus n. sp. (ventral view). Male. Head (Hd), trunk (Tr), posterior region (Pr), anterior locomotor appendage (Al), posterior locomotor appendage (Pl), antennae (T1, T2, T3), lateral cirri (C1, C2, C3), posterior cirrus (C4), lobe (Lb), maxilla $(\mathrm{Mx})$, mandible (Md), penis (P). (b) Male. Photomicrograph. Scale bar: $150 \mu \mathrm{m}$.

Municipality of São Pedro, State of São Paulo, Brazil, coll. Pr. Adão J. Cardoso, 18.I.1974.

Additional material. - (1) Peroba Cave, Municipality of São Pedro, State of São Paulo, Brazil, host: Aegla perabae, coll. Dr. Adão J. Cardoso, 18.I.1974: two males, two females and one immature.

(2) Creeks near Jaraguá Peak, Municipality of São Paulo, State of São Paulo, Brazil, host Aegla sp., coll. Dr. Carlos E. F. da Rocha, 8.VIII.1995: one male (MHN-BPO-67), two females (MHN-BPO-66, MHN-BPO-68) and two immatures (MHN-BPO69, MHN-BPO-70).

Description. - Mean total body length for adults and immatures 0.7 and $0.39 \mathrm{~mm}$, and length of jaw apparatus 134 and $102 \mu \mathrm{m}$, respectively. Antennae very long, as follows: median (T1) and first lateral pair (T2) almost half as long as head length

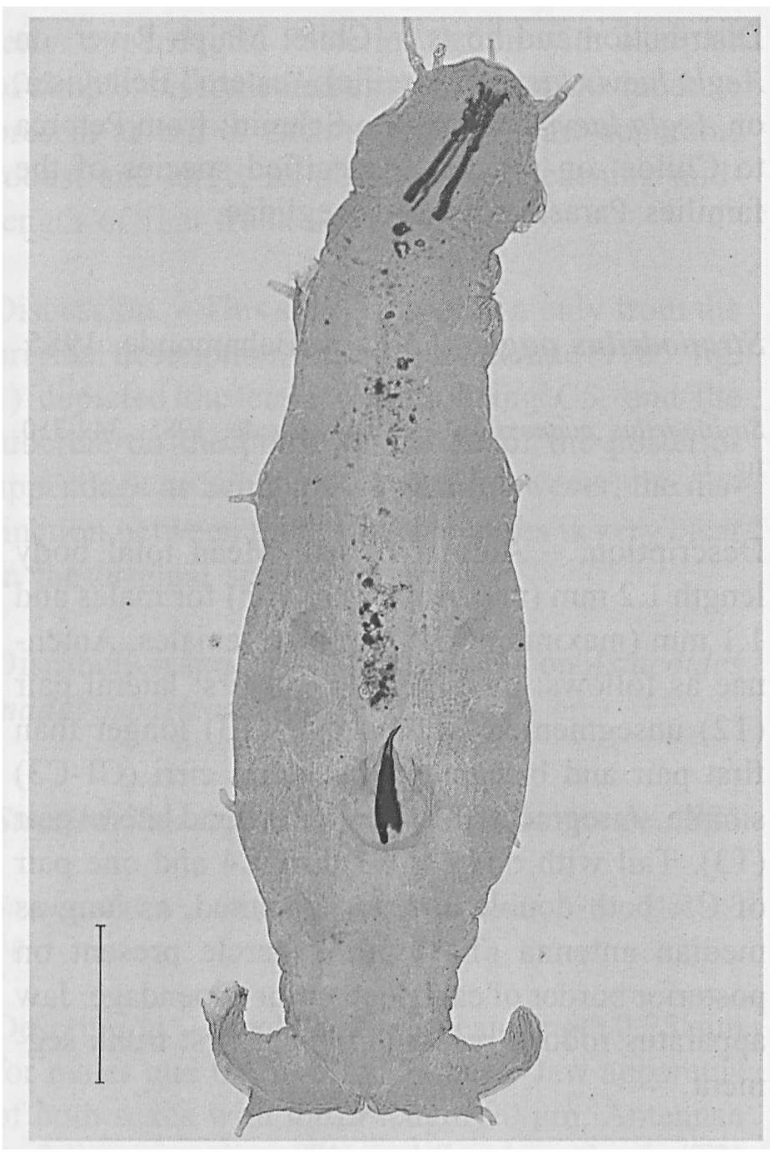

b.

and unsegmented; second pair (T3) twice as long as first pair, bisegmented, with another crown of cilia surrounding its articulation. Anterior locomotor appendages almost as long as T2. First segment of trunk half as long as head length. Lateral cirri (C1-C3) simple, unsegmented, as long as median antenna (T1). Each posterior locomotor appendage bears one simple, unsegmented cirrus (C4), as long as lateral cirri; a small papilliform lobe, smaller than $\mathrm{C} 4$; and one ciliated tubercle on posterior border. Jaw apparatus very long, its posterior end exceeding first trunk segment.

Discussion. - On reexamining the holotype and additional specimens from Peroba Cave and Jaraguá 


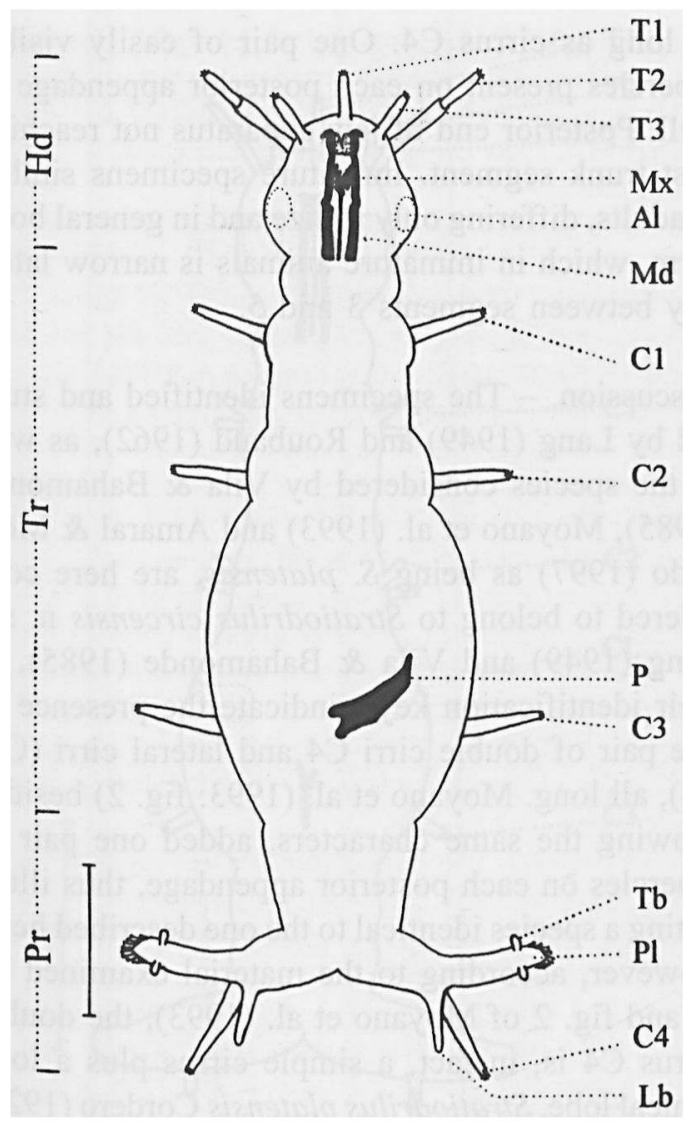

a.

Fig. 3. (a) Stratiodrilus circensis n. sp. (ventral view). Male. Tubercles (Tb). Other abbreviations as in Fig. 2a. (b) Female. Photomicrograph. Scale bar: $150 \mu \mathrm{m}$.

Peak, we verified that the basal support described by Amaral \& Morgado, 1997 is in fact a small lobe very close to $\mathrm{C} 4$. Additional small tubercles were visible on a few individuals from Peroba Cave. These structures were more easily visible on individuals from Jaraguá Peak.

Distribution and hosts. - Brazil: Peroba Cave in Municipality of São Pedro, State of São Paulo, on Aegla perobae Hebling \& Rodrigues; creeks near Jaraguá Peak in Municipality of São Paulo, State of São Paulo, on Aegla sp.

\section{Stratiodrilus robustus n. sp. (Fig. 2a-b)}

Material examined. - Holotype: adult specimen, male, MHNBPO-55, host Trichodactylus sp., stream near Ribeira Valley,

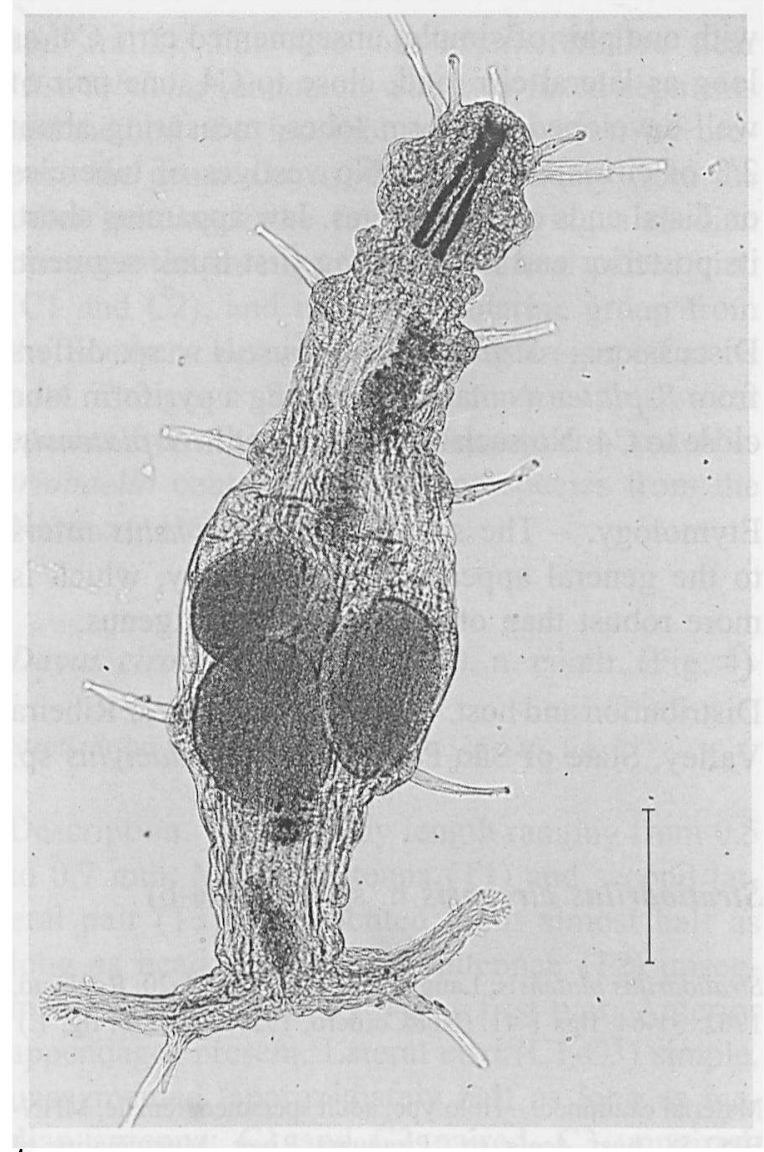

b.

State of São Paulo, Brazil, coll. Dr. Edmundo F. Nonato, 15.X.1972. Paratype series: From type locality, host Trichodactylus sp., coll. Dr. Edmundo F. Nonato, 15.X.1972. Paratype 1, adult specimen, male, MHN-BPO-56; Paratype 2, adult specimen, female, MHN-BPO-57.

Additional material. - (1) Espraiado River, municipality of Iguape, State of São Paulo, Brazil, host: Trichodactylus sp., coll. Dr. José Sabino, 23.VI.1993: one male, MHN-BPO-65.

Description. - Length of holotype $1.0 \mathrm{~mm}$; length of 2 adult paratypes 0.92 and $0.97 \mathrm{~mm}$. Jaw apparatus length: holotype $140 \mu \mathrm{m}$, paratypes 125 and $133 \mu \mathrm{m}$. Species robust. Antennae as follows: median (T1) and first lateral pair (T2) 1/5 as long as head length; second lateral pair (T3) twice as long as first pair; T2 unsegmented and T3 bisegmented. First segment of trunk $1 / 3$ as long as head length. Lateral cirri (C1-C3) simple, unsegmented, as long as first pair of antennae. Posterior region 
with one pair of simple, unsegmented cirri $\mathrm{C4}$, as long as lateral cirri and, close to $\mathrm{C} 4$, one pair of well-developed pyriform lobes, measuring about 2/3 of cirrus $C 4$ length. No vestiges of tubercles on distal ends of appendages. Jaw apparatus short, its posterior end not reaching first trunk segment.

Discussion. - Stratiodrilus robustus n. sp. differs from $S$. platensis mainly in having a pyriform lobe close to C4. No such lobe is present in S. platensis.

Etymology. - The specific name robustus refers to the general appearance of the body, which is more robust than other species of the genus.

Distribution and host. - Brazil: streams near Ribeira Valley, State of São Paulo, on Trichodactylus sp.

Stratiodrilus circensis n. sp. (Fig. 3a-b)

Stratiodrilus platensis; Lang, 1949: 1-30, figs. 1-20; Roubaud, 1962: 31-64, fígs 1-41. (Not Cordero, 1927: 574-578, fig. 1.)

Material examined. - Holotypex adult specimen, female, MHNBPO-58, host Aegla sp., Piraquara River, Municipality of Piraquara, State of Paraná, Brazil, coll. Dr. Walter A. P. Böeger, 20.VI.1994. Paratype series: From type locality, host Aegla sp., coll. Dr. Walter A. P. Bōeger, 20.VI.1994. Paratype 1 adult specimen, female, MHN-BPO-59; paratypes 2 and 3, adult specimens, males, MHN-BPO-60 and MHN-BPO-61; paratypes 4 and 5, immature specimens, MHN-BPO-62 and MHN-BPO63.

Description. - Length of holotype $0.9 \mathrm{~mm}$; lengthts of 3 adult paratypes $0.79-0.83 \mathrm{~mm}$; lengths of 2 immature paratypes 0.62 and $0.70 \mathrm{~mm}$. Jaw apparatus of holotype measuring $142 \mu \mathrm{m}$, of the three adult paratypes $118-144 \mu \mathrm{m}$, of the two immatures $115 \mu \mathrm{m}$. Antennae very long, median (T1) and first lateral pair (T2) of equal length, both $1 / 4$ as long as head length, T2 unsegmented; second lateral pair long, three times as long as median antenna. First segment of trunk 1/5 as long as head length. Lateral cirri (C1-C3) longer than first pair of antenna. Each posterior appendage bearing one very long ventral unsegmented cirrus $\mathrm{C} 4$, as long as lateral cirri and, close to $\mathrm{C} 4$, one long conical lobe, half as long as cirrus $\mathrm{C} 4$. One pair of easily visible tubercles present on each posterior appendage as well. Posterior end of jaw apparatus not reaching first trunk segment. Immature specimens similar to adults, differing only in size and in general body form, which in immature animals is narrow laterally between segments 3 and 5 .

Discussion. - The specimens identified and studied by Lang (1949) and Roubaud (1962), as well as the species considered by Vila \& Bahamonde (1985), Moyano et al. (1993) and Amaral \& Morgado (1997) as being $S$. platensis, are here considered to belong to Stratiodrilus circensis n. sp. Lang (1949) and Vila \& Bahamonde (1985), in their identification keys, indicate the presence of one pair of double cirri $\mathrm{C} 4$ and lateral cirri (C1C3), all long. Moyano et al. (1993: fig. 2) besides showing the same characters, added one pair of tubercles on each posterior appendage, thus illustrating a species identical to the one described here. However, according to the material examined by us and fig. 2 of Moyano et al. (1993), the double cirrus $\mathrm{C} 4$ is, in fact, a simple cirrus plus a long conical lobe. Stratiodrilus platensis Cordero (1927) bears short cirri (C1-C4), only one pair of simple cirri $\mathrm{C} 4$, and no tubercles.

Etymology. - The name of the family (Histriobdellidae) makes reference to the clown, a circus artist. The specific name circensis is in honor of all circus artists.

Distribution and hosts. - Argentina: Rio Negro and lakes in Parque Nacional de Nahuel Huapí, on Aegla laevis (Latreille); Chico River (Tucumán), on Aegla neuquensis neuquensis (Schmitt); - Chile: Lake Riñihue, on Aegla laevis (Latreille) and Aegla sp.; Tólten River, on Aegla bahamondei Jara and Aegla abtao Schmitt; from Petorca to Chiloé, on several unspecified species of the families Aeglidae and Parastacidae; - Brazil: Piraquara River, State of Paraná, on Aegla sp. The data on geographical distribution provided by Moyano et al. (1993), Lang (1949), and Roubaud (1962), initially attributed to $S$. platensis, are attributed here to $S$. circensis n. sp. 


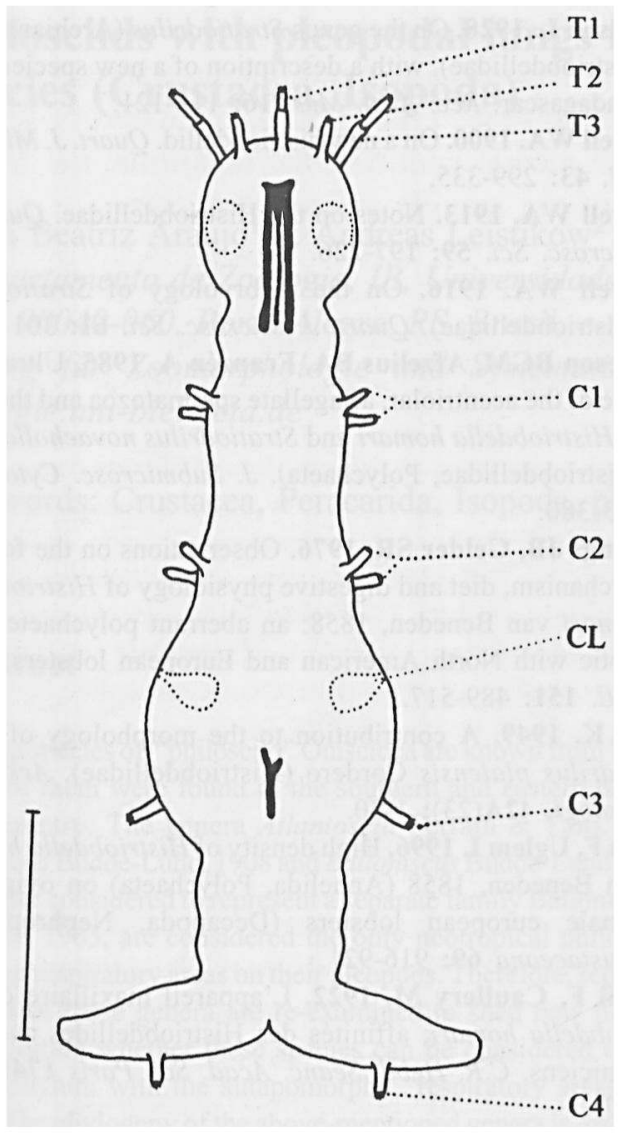

Fig. 4. Dayus cirolanae (Führ, 1971) (ventral view). Male. Clasper (CL). Other abbreviations as in Fig. 2a. Scale bar: 150 $\mu \mathrm{m}$. Adapted from Führ (1971).

\section{Dayus n. gen.}

Diagnosis. - Median antenna (T1) bisegmented, first lateral pair (T2) unsegmented and short, second pair (T3) bisegmented, and longer than first pair. Lateral cirri simple, unsegmented, $\mathrm{C} 1$ and $\mathrm{C} 2$ paired, C3 not paired. Posterior region apparently composed of two fused segments. Eggs fixed to the host by one end.

Type-species. - Stratiodrilus cirolanae Führ, 1971

Etymology. - Named in honor of the eminent polychaetologist John H. Day, who identified the type species for Führ, in 1971.

Discussion. - The type species, $S$. cirolanae, shows characteristics close to the genus Stratiodrilus (head and trunk), but also has characteristics near Histriobdella (abdomen with two fused segments and method of oviposition of the female). We propose the genus Dayus, differing mainly from the other genera of the family in having a median bisegmented antenna (T1) and lateral paired cirri ( $\mathrm{C} 1$ and $\mathrm{C} 2$ ), and in being a marine group from the Southern Hemisphere, having an isopod as its host. The genus Stratiodrilus contains freshwater species from the Southern Hemisphere, and Histriobdella contains one marine species from the Northern Hemisphere.

Dayus cirolanae (Führ, 1971), n. comb. (Fig. 4)

Stratiodrilus cirolanae Führ, 1971: 325-326, fig. 1.

Description. - Total body length ranging from 0.5 to $0.7 \mathrm{~mm}$. Median antenna (T1) and second lateral pair (T3) bisegmented, both almost half as long as head; first pair of antennae (T2) unsegmented, about half as long as first pair. Anterior appendages present. Lateral cirri (C1-C3) simple, unsegmented, approximately half as long as median antenna; $\mathrm{C} 1$ and $\mathrm{C} 2$ paired, C3 unpaired. Claspers present. Posterior region with one pair of simple cirri (C4), unsegmented. Lobes and tubercles absent. Jaw apparatus very long, its posterior end reaching midlength of first trunk segment.

Distribution and host. - South Africa: from Langebaan Lagoon, East London, on pleopods of the marine isopod Cirolana venusticauda var. simplex Barnard.

\section{Acknowledgements}

We are deeply grateful to Dr. W. A. P. Böeger, Dr. E. F. Nonato and Dr. C. E. F. da Rocha for the donation of the specimens examined. Thanks to the anonymous reviewers for their critical comments and valuable suggestions. Dr. Janet W. Reid revised the English text.

\section{References}

Amaral ACZ, Morgado EH. 1997. Stratiodrilus (Annelida: Polychaeta: Histriobdellidae) associated to a freshwater 
decapod, with the description of a new species. Proc. Biol. Soc. Wash. 110: 471-475.

Beneden PJ van. 1858. Histoire naturelle d'un animal nouveau, désigné sous le nom d'Histriobdella. Bull. Acad. Roy. Sci. Let. Beaux-Arts Belg. 2: 270-303.

Boghen AD. 1978. A parasitological survey of the American lobster Homarus americanus from the Northumberland Strait, southern Gulf of St. Lawrence. Can. J. Zool. 56: 2460-2462.

Brattey J, Campbell A. 1985. Occurrence of Histriobdella homari (Annelida: Polychaeta) on the American lobster in the Canadian Maritimes. Can. J. Zool. 63: 392-395.

Briggs RP, Atkinson RJA, McAliskey M, Rogerson A. 1997. Histriobdella homari on Nephrops norvegicus from the Irish Sea and Clyde Sea area. J. Mar. Biol. Ass. U.K. 77: 557-559.

Cannon LRG, Jennings JB. 1987. Occurrence and nutritional relationships of four ectosymbiotes of the freshwater crayfishes Cherax dispar Riek and Cherax punctatus Clark (Crustacea: Decapoda) in Queensland. Aust. J. Mar. Freshw. Res. 38: 419-427.

Cordero EH. 1927. Nuevo arquianélido Stratiodrilus platensis sp. n. que habita sobre Aegla laevis (Latr.). Physis (Revista de la Sociedad Argentina de Ciencias Naturales) 8: 574578.

Dioni W. 1972. Didymorchis, Temnocephala (Platyhelmintha) y Stratiodrilus (Annelida), vermes epizóicos sobre Aegla y Parastacus (Crustacea: Decapoda) de lagos andinopatagonicos. Notas taxinomicas y biogeograficas. Acta Zool. Lilloana 29: 167-179.

Engel WA. van, Harris RE, Zwerner DE. 1986. Occurrence of some parasites and a commensal in the American lobster, Homarus americanus, from the mid-Atlantic Bight. Fish. Bull. 84: 197-200.

Fauchald K, Rouse G. 1997. Polychaete systematics: past and present. Zoologica Scripta 26: 71-138.

Fauvel P. 1923. Faune de France 5. Polychètes Errantes (Libraire de la Faculté des Sciences): 1-488.

Foettinger A. 1884. Recherches sur l'organisation de Histriobdella homari P. J. van Beneden rapportée aux Archiannélides. Arch. Biol. Liége 5: 435-516.

Führ IM. 1971. A new histriobdellid on a marine issopod from South Africa. S. Afr. J. Sci. 67: 325-326.

Gelder SR, Jennings JB. 1975. The nervous system of the aberrant symbiotic polychaete Histriobdella homari and its implications for the taxonomic position of the Histriobdellidae. Zool, Anz, Jena 194: 293-304.

Gelder SR, Tyler S. 1986. Anatomical and cytochemical studies on the adhesive organs of the ectosymbiont Histriobdella homari (Annelida: Polychaeta). Trans. Amer. Microsc. Soc. 105: 348-356.

George JD, Hartmann-Schröder G. 1985. Polychaetes: British Amphinomida, Spintherida \& Eunicida. Synopses of the British Fauna 32 (The Linnean Society of London and The Estuarine and Brackish-Water Sciences Assoc.): 1221.
Harrison L. 1928. On the genus Stratiodrilus (Archiannelida: Histriobdellidae), with a description of a new species from Madagascar. Rec. Aust. Mus. 16: 116-121.

Haswell WA. 1900. On a new histriobdellid. 2uart. J. Microse. Sei. 43: 299-335.

Haswell WA. 1913. Notes on the Histriobdellidae. Quart. $J$. Microsc. Sci. 59: 197-226.

Haswell WA. 1916. On the embryology of Stratiodrilus (Histriobdellidae). Quart. J. Microsc. Sci. 61: 301-312.

Jamieson BGM, Afzelius BA, Franzén A. 1985. Ultrastructure of the acentriolar, aflagellate spermatozoa and the eggs of Histriobdella homari and Stratiodrilus novaehollandiae (Histriobdellidae, Polychaeta). J. Submicrosc. Cytol. 17: 363-380.

Jennings JB, Gelder SR. 1976. Observations on the feeding mechanism, diet and digestive physiology of Histriobdella homari van Beneden, 1858: an aberrant polychaete symbiotic with North American and European lobsters. Biol. Bull. 151: 489-517.

Lang K. 1949. A contribution to the morphology of Stratiodrilus platensis Cordero (Histriobdellidae). Arkiv för Zoologi, 42A(23): 1-30.

Lerch F, Uglem I. 1996. High density of Histriobdella homari van Beneden, 1858 (Annelida, Polychaeta) on ovigerous female european lobsters (Decapoda, Nephropidae). Crustaceana 59: 916-921.

Mesnil F, Caullery M. 1922. L'appareil maxillaire d'Histriobdella homari; affinítés des Histriobdellides avec les Euniciens. C.R. Hebd. Séanc. Acad. Sci. Paris 174: 913917.

Moyano HI, Carrasco F, Gracitúa S. 1993. Sobre las especies chilenas de Stratiodrilus Haswell, 1900 (Polychaeta, Histriobdellidae). Bol. Soc. Biol. Concepción, Chile 64: 147157.

Roubaud G. 1962. Recherches sur les Stratiodrilus platensis Cordero, archiannélides parasites des Aeglae des lacs de Patagonie. In: Deboutteville CD, Rapport E, eds, Biologie de l'Amérique australe II. Etudes sur les faunes du sol: 31-54.

Shearer C. 1910. On the anatomy of Histriobdella homari. Quart. J. Microsc. Sci. 55: 287-359.

Simon JL. 1968. Incidence and behavior of Histriobdella homari (Annelída; Polychaeta) a commensal of the American lobster, Bioscience 18: 35-36.

Uzmann JR. 1967. Histriobdella homari (Annelida: Polychaeta) in the American lobster, Homarus americanus. $J$. Parasitol. 53: 210-211.

Vaillant L. 1890. Hîstoíre Naturelle des Annelés Marins et d'Eau Doucex Lombriciens, Hirudiniens, Bdellomorphes, Térétulariens et Planariens, 3. Paris: Roret.

Vila PI, Bahamonde N. 1985. Two new species of Stratiodrilus, S. aeglaphilus and $S$. pugnaxi (Annelida: Histriobdellidae) from Chile. Proc. Biol. Soc. Wash. 98: 347-350.

Received: 11 December 1997 